\title{
Study of Infection Impact by Entamopathogenic Fungi on some Biochemical Contents in Haemolymph of Cotton Leaf Worm, Spodoptera littoralis (Boisduval) \\ El-Badawy, S. S. ; Sahar S. Ali ; A. A. El-Hefny and Gamila A. M. Heikal \\ Plant Prot. Res. Inst., Agric. Res. Center, Dokki, Giza, Egypt.
}

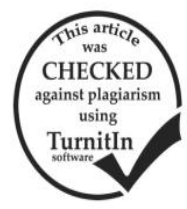

\section{ABSTRACT}

Carbohydrates, lipids and proteins contents were evaluated in $5^{\text {th }}$ larval instar haemolymph of Spodoptera littoralis (Boisd.) that treated with four isolates of entomopathogenic fungi Beauveria bassiana, Metarhizium anisopliae, Paecilomyces lilacinus and Lecanicillium antillanum at $1^{\text {st }}, 2^{\text {nd }}, 3^{\text {rd }}$ and $4^{\text {th }}$ days. Generally, data in present work cleared that, there was significant decrease in haemolymph carbohydrates of larvae injected with the entomopathogenic fungi in the three time intervals $\left(1^{\text {st }}, 2^{\text {nd }}\right.$ and $\left.3^{\text {rd }}\right)$ under investigation compared to control. The concentration level of protein content of larvae injected with the fungi significantly increased as compared with control insects in $\left(1^{\text {st }}\right)$ day, then there is no significant change in the content after $2^{\text {nd }}$ and $3^{\text {rd }}$ day except increasing was noticed with the two fungi (B. bassiana and $L$. antillanum). There were significant increases of carbohydrates and protein contents observed in the last day ( $4^{\text {th }}$ day) due to effect of fungal infection. Significant increases of lipid content was noticed in the $5^{\text {th }}$ instar cotton leaf worm larvae inoculated with the four tested fungi from $1^{\text {st to }} 4^{\text {th }}$ day. The overall results indicated that total $S$. littoralis larvae proteins, carbohydrates and lipids contents vary significantly during infection of the tested fungi at the four time intervals $\left(1^{\text {st }}, 2^{\text {nd }}\right.$ $3^{\text {rd }}$ and $4^{\text {th }}$ days) and this tend to dramatically changes in the composition of haemolymph, thus abnormal growth and development of insect caused.

Keywords: Carbohydrates, lipids and proteins contents, Fungi, Spodoptera littoralis.

\section{INTRODUCTION}

The action of entomopathogenic fungi caused mortality in tested pests; the agents are safe and worldwide interest of improvement and using for insect biological control. The infect by entomopathogenic fungi caused it reaches to hemocoel, and blastospores produces are final pathogenic stage of infection host (Vincent et al., 2007). The insects Haemolymph is a medium for some processes of physiological, such as, intermediary of metabolism and responses of immune. When enters the invader to insects hemocoel, the hemocytes are engaged to remove non-selftarget by phagocytosis, encapsulation, nodule form, antimicrobial peptides synthesis and reaction of metabolites (Beckage, 2008). The haemolymph of Insects, Consists of complex mixture of lipids, proteins, acids, carbohydrates, hormones and degradation product of them, is primary response for nutrients supply, metabolic transferring wastes to normal maintain of development and growth. Only haemolymph is a extracellular fluid of insects with various functions and products reservoir required for physiological activities of insect body, the composition changes of haemolymph reflect biochemical and physiological transformations in tissues of insect (Pawar and Ramakrishnan1977).

The bio-molecules (carbohydrates, proteins and lipids) play a principle role in the development and morphogenesis in the intermediary metabolic pathways of insects. Intermediary metabolism consists of various pathways in which ingested and stored nutrients such as carbohydrates, lipids and proteins are processed to produce energy via their degradation or synthesis (Nation, 2008).

Spodoptera littoralis (Boisduval), the Egyptian cotton leaf worm (Lepidoptera: Noctuidae) is the serious polyphagous insect, it an economically important pest of many agricultural crops. It was reported that it can attack 112 plant species belonging to 44 families (Mallikarjuna et al., 2004). Many entomopathogenic fungi were found to be efficient biological agents to control this pest. Although extensive studies have been conducted on the process of cuticle penetration by entomopathogenic fungi effect of entomopatognic fungi on haemolymph components still under-explored. Pathogenicity of entomopathogenic fungi may occur via overcoming on immune responses and discrepancies of intermediary metabolisms. The progress of infection by a pathogen in the host tissue can be monitored by studying the degree of variation in metabolic constituents (Rajitha and Savithri 2014).This may be caused an impact on the role of enzymes in insect resistance to entomopathogenic fungi for this, it was necessary to continue studies to evaluate the influence of four isolates of entomopathogenic fungi on some biochemical changes in haemolymph components of $S$. littoralis.

\section{MATERIALS AND METHODS}

\section{Insect used}

Newly moulted $5^{\text {th }}$ instar larvae of Spodoptera. littoralis Bois. were obtained from culture reared for several generations on castor leaves under laboratory conditions $\left(27.0 \pm 1.0^{\circ} \mathrm{C}\right.$ and $\left.70.0 \pm 5.0 \% \mathrm{RH}\right)$.

\section{Fungal cultures}

Blastospores cultures of entomopathogenicfungi, Beauveria bassiana, Metarhizium anisopliae, Paecilomyces lilacinus and Lecanicillium antillanum produced by inoculating conidia into Sabouraud Dextrose broth. This medium was prepared and adjusted at $\mathrm{pH}$ (5.56.0). The culture was inoculated at $25 \pm 10^{\circ} \mathrm{C}$ on shaker for 5 days. The culture was filtered through sterilized glass wool to remove mycelia. Blastospores were collected from filtrates by centrifugation and washed twice in a sterile solution of $0.85 \%$ saline. Fungal cells were counted on a hemacytometer and diluted in sterile saline solution to a concentration of $1 \times 10^{7}$ blastospores $\mathrm{ml}$ for entomopathogenic fungi . Five $\mu \mathrm{l}$ of the concentration were injected into the hemocoeles of fifth instar of $S$. littoralis larvae.The control larvae injected with five $\mu$ of sterile $0.85 \%$ saline solution. While the treated and control larvae were placed in sterile batches containing cleaned castor bean leaves, and then incubated at $25 \pm 10^{\circ} \mathrm{C}$ and $75 \pm 5 \%$ $\mathrm{RH}$. The injected larvae were surface sterilized with $70 \%$ ethanol and rinsed twice with sterile distilled water (Gabarty et al.,2013). 


\section{Collection of haemolymph}

After 1, 2, 3 and 4 days of the induction with fungal pathogen, haemolymph was collected from $5^{\text {th }}$ instar $S$. littoralis larvae into eppendorf tubes containing a few milligrams of phenylthiourea to prevent the inhibitory effect of tyrosinase (Abou El-Ghar et al., 1996) by clipping third pair of abdominal legs of larvae.

Biochemical assays:

Estimation of the total haemolymph proteins.

Proteins content of $S$. littoralis haemolymph was determined spectro-photometrically according to Bradford (1976) with bovine serum albumin (BSA) as the standard protein solution. The method depends on the protein forms a violet complex with cupric ions in alkaline medium. The absorbance at $595 \mathrm{~nm}$ was measured after 2 minutes and before 1 hour, against a blank. Proteins content was expressed as $\mathrm{mg} / \mathrm{ml}$ haemolymph.

Estimation of the total haemolymph carbohydrates

Total carbohydrate content in haemolymph was quantitatively determined by phenol-sulfuric acid reaction according to Dubois et al., (1956). The absorbance of yellow-orange color was measured at $490 \mathrm{~nm}$ against blank. Total carbohydrates content were calculated and expressed as $\mathrm{mg} / \mathrm{ml}$ haemolymph.

\section{Estimation of the total haemolymph lipids}

Total lipids were determined according to Knight et al., (1972). The developing rose color was measured at 525 $\mathrm{nm}$ against a blank. Lipids content was expressed as $\mathrm{mg}$ $/ \mathrm{ml}$ haemolymph.

Statistical analysis:

Data of all experiments were evaluated statistically using ANOVA and means were compared using Duncan's Multiple Range Test at $(\mathrm{P}<0.05)$. All statistical analyses were done using the software package Costat.

\section{RESULTS AND DISCUSSION}

This study gives basic information about how the insect haemolymph nutrients could be affected due to injection with high virulent of entomopathogenic fungi. The difference in the total protein, carbohydrates and lipids contents in haemolymph from $1^{\text {st }}$ to $4^{\text {th }}$ days during $5^{\text {th }}$ instar development in Spodoptera. littoralis Bois. infected with four fungi were studied.

\section{1- Effect of fungi on haemolymph protein content.}

The investigation of biochemical changes in haemolymph protein content level $(\mathrm{mg} / \mathrm{ml})$ of the $5^{\text {th }}$ instar larvae of $S$. littoralis injected by $1 \times 10^{7}$ blastospores $/ \mathrm{ml}$ of four entomopathogenic fungi, B. bassiana, M. anisopliae, $P$. lilacinus and $L$. antillanum after 1, 2, 3 and 4 days, demonstrated in (Table 1).
Results showed that the four fungi caused increase in haemolymph protein content of the treated $S$. littoralis $5^{\text {th }}$ instar at $1^{\text {st }}$ day, the highest increasing were recorded with L. antillanum $(25.00 \mathrm{mg} / \mathrm{ml})$ then $M$. anisopliae $(21.80 \mathrm{mg} / \mathrm{ml})$, B. bassiana $(20.00 \mathrm{mg} / \mathrm{ml})$ and finally $P$. lilacinus $(19.8 \mathrm{mg} / \mathrm{ml})$, compared to control $(18.2 \mathrm{mg} / \mathrm{ml})$. The increasing of protein content continued at the $2^{\text {nd }}$ day with $B$. bassiana $(39.60 \mathrm{mg} / \mathrm{ml})$, but, there were decreases in protein content with $P$. lilacinus $(31.00 \mathrm{mg} / \mathrm{ml}), M$. anisopliae $(30.40 \mathrm{mg} / \mathrm{ml})$ and L. antillanum $(29.60 \mathrm{mg} / \mathrm{ml})$ compared to control $(32.00 \mathrm{mg} / \mathrm{ml})$ at the same day. At the $3^{\text {rd }}$ day, only protein content of $M$. anisopliae $(46.00 \mathrm{mg} / \mathrm{ml})$ and $B$. bassiana $(42.60 \mathrm{mg} / \mathrm{ml})$ were higher than control $(37.80 \mathrm{mg} / \mathrm{ml})$ while, the other three fungi showed decreased protein content. There was increase in protein content at the last day ( $4^{\text {th }}$ day) with all tested fungi except $M$. anisopliae $(23.80 \mathrm{mg} / \mathrm{ml})$. The other fungi achieved increasing protein content as follow $P$. lilacinus $(33.80 \mathrm{mg} / \mathrm{ml}), \quad B$. bassiana $(31.00 \mathrm{mg} / \mathrm{ml})$ and $L$. antillanum $(30.80 \mathrm{mg} / \mathrm{ml})$ compared to control $(25.60 \mathrm{mg} / \mathrm{ml})$. The results of the study shows a series of variations in total protein content in $5^{\text {th }}$ instar $S$. littoralis larvae infected with four fungal pathogens.

Highly significant protein levels (increase)were noticed in the larvae of $5^{\text {th }}$ instar $S$. littoralis from $1^{\text {st }}$ day to $3^{\text {th }}$ day with the fungal pathogen of M. anisopliae (21.80 to $46.00 \mathrm{mg} / \mathrm{ml})$ and $B$. bassiana $(20.00$ to $42.60 \mathrm{mg} / \mathrm{ml}$ ), whereas, significant variations (decrease) in total protein content were recorded with $P$. lilacinus $(19.80$ to $33.80 \mathrm{mg} / \mathrm{ml})$, L. antillanum $(25.00$ to $31.00 \mathrm{mg} / \mathrm{ml}$ ) from $1^{\text {st }}$ day to $3^{\text {th }}$ day compared to the control variations (18.20 to $37.80 \mathrm{mg} / \mathrm{ml}$ ) at the same periods. But, there were decreasing in protein levels were noticed from $3^{\text {th }}$ to the last day $\left(4^{\text {th }}\right.$ day) of inoculated $S$. littoralis with the four fungi and control (Table 1). Generally, in the control and the four fungi, protein level increased day by day from $1^{\text {st }}$ to $3^{\text {th }}$ day, but decrease with the last day. In general, the protein content level of the $5^{\text {th }}$ instar larvae of $S$. littoralis in the haemolymphwas found maximum on third day, but decreased at the last day $4^{\text {th }}$ day, due to fungi infection. The overall results showed, there are increasing in the haemolymph protein content with increasing of time.

Proteins are fundamental components of all living cells and include many substances, such as enzymes, hormones, and antibodies that are necessary for the proper functioning of an organism. The digestive activities are high during the early part of $5^{\text {th }}$ instars development, so protein content from first day to third day was increased, which results in increased accumulation of proteins that are then transported to other tissues through the haemolymph for further physiological activities (Horie et al., 1982).

Table 1. Effect of five entomopathogenic fungi on proteins content $(\mathrm{mg} / \mathrm{ml})$ in haemolymph of $5^{\text {th }}$ instar larvae of Spodoptera littoralis.

\begin{tabular}{|c|c|c|c|c|}
\hline \multirow{3}{*}{ Treatments } & \multicolumn{4}{|c|}{ Protein Mean \pm S.D $(\mathrm{mg} / \mathrm{ml})$} \\
\hline & \multicolumn{4}{|c|}{ Time (days) } \\
\hline & 1st & 2nd & 3rd & 4th \\
\hline Control & $18.20 \pm 0.74 d$ & $32.00 \pm 0.47 \mathrm{c}$ & $37.80 \pm 1.06 \mathrm{c}$ & $25.60 \pm 0.33 d$ \\
\hline M. anisopliae & $21.80 \pm 0.30 \mathrm{~b}$ & $30.40 \pm 0.45 \mathrm{~d}$ & $46.00 \pm 0.25 \mathrm{a}$ & $23.80 \pm 0.95 \mathrm{c}$ \\
\hline P.lilacinus & $19.80 \pm 0.35 c$ & $31.00 \pm 0.25 \mathrm{~d}$ & $33.80 \pm 0.60 \mathrm{~d}$ & $33.80 \pm 0.40 \mathrm{a}$ \\
\hline L. antillanum & $25.00 \pm 0.25 \mathrm{a}$ & $29.60 \pm 0.35 \mathrm{e}$ & $31.00 \pm 0.20 \mathrm{f}$ & $30.80 \pm 0.40 b$ \\
\hline B. bassiana & $20.00 \pm 0.21 \mathrm{c}$ & $39.60 \pm 0.45 a$ & $42.60 \pm 0.35 b$ & $31.00 \pm 0.55 b$ \\
\hline F value & $43.94 * * *$ & $239.18 * * *$ & $598.06 * * *$ & $157.99 * * *$ \\
\hline$\overline{\mathrm{LSD} 0.05}$ & 1.09 & 0.744 & 0.744 & 0.744 \\
\hline
\end{tabular}


Nirupama, (2015) showed that, the inoculated batches of protein content level of silkworm, Bombyx mori was maximum on third day in the haemolymph and decreased gradually towards the end of $4^{\text {th }}$ and $5^{\text {th }}$ days due to the fungi infection. Also our results were confirmed by Vidhya, et al (2016) they stated that, infection of the army worm Spodoptera litura (Fabricius) by three fungal pathogens $B$. bassiana, M.anisopliaeand Verticillum lecanii showed significant increase of protein content at $48 \mathrm{hrs}$ and significantly decreased at the $96 \mathrm{hrs}$, as compared to control.In contrast, Padma and Ramani (2015)found that the larvae of mulberry silkworm, B. mori fed with $B$. bassiana treated leaves at $1^{\text {st }}$ to $6^{\text {th }}$ day of the fifth instar recorded decrease in protein content compared to control. Also, Nada, (2015) reported that, the total of protein level of adult Nezara virdula treated with $M$. anisopliae were significantly decreased than the treatment with $B$. bassiana, after 24, 48 and $72 \mathrm{hrs}$.

\section{2- Effect of fungi on haemolymph carbo hydrates} content.

Total carbohydrates content divergence in haemolymph of $5^{\text {th }}$ instars $S$. littoralis was presented in (Table 2).

A significant increase was recorded in the $1^{\text {st }}$ day of fungal infection with $B$. bassiana, $(13.2 \mathrm{mg} / \mathrm{ml})$ and $L$. antillanum $(12.3 \mathrm{mg} / \mathrm{ml})$ compared to control $(10.30$ $\mathrm{mg} / \mathrm{ml}$ ), but, there were noticed a significant decrease was recorded with $M$. anisopliae $(6.80 \mathrm{mg} / \mathrm{ml})$ and $P$. lilacinus
$(8.80 \mathrm{mg} / \mathrm{ml})$ at the same day. Then fungi at $2^{\text {nd }}$ and $3^{\text {rd }}$ day, $M$. anisopliae $(10.40$ and $12.90 \mathrm{mg} / \mathrm{ml}), \quad P$. lilacinus(12.60and13.90 mg/ml), L. antillanum $(11.00$ and $10.50 \mathrm{mg} / \mathrm{ml})$ and $B$. bassiana $(10.30$ and $8.10 \mathrm{mg} / \mathrm{ml})$ respectively, were caused significant variation (reduction) in carbohydrates content ompared to their control (13.30 and $14.70 \mathrm{mg} / \mathrm{ml}$ ) respectively. There was increase in all fungi again noticed at the last day ( $4^{\text {th }}$ day).

Results cleared that only three fungi caused increase in the haemolymph carbohydrates content of the infected $S$. littoralis $5^{\text {th }}$ instar from $1^{\text {st }}$ to $3^{\text {rd }}$ day, these increasing ranged from 6.80 to $12.90 \mathrm{mg} / \mathrm{ml}$ recorded with M. anisopliae, and 8.80 to $13.90 \mathrm{mg} / \mathrm{ml}$ recorded with $P$. lilacinus. The other two entemopathogenic fungi $L$. antillanum and $B$. bassiana decreased carbohydrates content from 12.3 to $10.50 \mathrm{mg} / \mathrm{ml}$ and from 13.20 to 8.10 $\mathrm{mg} / \mathrm{ml}$ respectively at the same time period. There were decreasing in carbohydrates levels noticed on the last day ( $4^{\text {th }}$ day) of inoculated $S$. littoralis except $L$. antillanum and $B$. bassiana recorded increasing in carbohydrates levels compared to control. On other hand, haemolymph carbohydrates content of control increased from 10.30 at $1^{\text {st }}$ to $14.7 \mathrm{mg} / \mathrm{ml}$ at $3^{\text {rd }} \mathrm{day}$, then significant reduction occurred at $4^{\text {th }}$ day $(9.20 \mathrm{mg} / \mathrm{ml})$ (Table 2$)$. In general, there are increasing in the haemolymph carbohydrates content with increasing of time from $1^{\text {st }}$ to $4^{\text {th }}$ day except there are decreasing recorded with $P$. lilacinus and $M$. anisopliae.

Table 2. Effect of five fungal pathogens on carbohydrates contents $(\mathrm{mg} / \mathrm{ml})$ in haemolymph of $5^{\text {th }}$ instar larvae of Spodoptera littoralis.

\begin{tabular}{|c|c|c|c|c|}
\hline \multirow{3}{*}{ Treatments } & \multicolumn{4}{|c|}{ Protein Mean \pm S.D $(\mathrm{mg} / \mathrm{ml})$} \\
\hline & \multicolumn{4}{|c|}{ Time (days) } \\
\hline & $1 \mathrm{st}$ & 2nd & 3rd & 4th \\
\hline Control & $10.30 \pm 0.30 c$ & $13.30 \pm 0.20 \mathrm{a}$ & $14.70 \pm 0.35 \mathrm{a}$ & $9.20 \pm 0.35 \mathrm{f}$ \\
\hline M. anisopliae & $6.80 \pm 0.25 \mathrm{e}$ & $10.40 \pm 0.50 \mathrm{e}$ & $12.93 \pm 0.45 \mathrm{~d}$ & $12.43 \pm 0.25 \mathrm{c}$ \\
\hline P.lilacinus & $8.80 \pm 0.60 \mathrm{~d}$ & $12.60 \pm 0.15 \mathrm{c}$ & $13.90 \pm 0.40 \mathrm{c}$ & $9.80 \pm 0.70 \mathrm{e}$ \\
\hline L. antillanum & $12.30 \pm 0.30 \mathrm{~b}$ & $11.00 \pm 0.25 \mathrm{~d}$ & $10.50 \pm 0.50 \mathrm{e}$ & $14.30 \pm 0.40 \mathrm{~b}$ \\
\hline B. bassiana & $13.20 \pm 0.35 \mathrm{a}$ & $10.30 \pm 0.45 \mathrm{e}$ & $8.10 \pm 0.06 \mathrm{f}$ & $17.70 \pm 0.85 \mathrm{a}$ \\
\hline F value & $93.69 * * *$ & $550.45^{* * * *}$ & $1966.40^{* * *}$ & $3382.6^{* * *}$ \\
\hline$\overline{\mathrm{LSD} 0.05}$ & 0.822 & 0.1779 & 0.1779 & 0.1677 \\
\hline
\end{tabular}

These results agree with Nada, (2015) mentioned the total protein level in adult of $N$. virdula when treated with $M$. anisopliae gave significantly decreased than others treated with $B$. bassiana during time 24,48 and $72 \mathrm{hrs}$. Also, Nirupama, (2015) showed that, total carbohydrates content level in the haemolymph of $B$. mori $5^{\text {th }}$ instar showed normal in the $1^{\text {st }}$ day and decreased gradually towards the end of $5^{\text {th }}$ day in inoculated batches. On other hand, the results of Meshrif et al., (2010) indicated that, there was initial significant increase in plasma carbohydrates of $S$. littoralis $5^{\text {th }}$ instar larvae when injected by fungi (Nomuraea rileyi and B. bassiana) and in the subsequent time intervals, no significant changes between the control and the infected insects were observedunder investigation.

Since, carbohydrates providing the major of energy sources production for growth cells and development, serve as structural blocks of cells building and intermediates of metabolic (Lee et al., 2002), so, the decreasing at $1^{\text {st }}, 2^{\text {nd }}$ and $3^{\text {rd }}$ day in the total carbohydrates of $S$. littoralis infected may be considered as energy reserves required for defense reactions and other vital processes. Also, the reduction significant of content carbohydrate noticed by $1^{\text {st }}, 2^{\text {nd }}$ and $3^{\text {rd }}$ day of inoculated larvae compared with control, may be due to carbohydrate utilization ceased by food intake and pathogen. Levels of carbohydrates were decreased in haemolymph and attributed to carbohydrate excessive utilization required to give energy of infection. Sarma et al., (1994). Reported that, the steady decreases in carbohydrate contents as infection of nuclear polyhedrosis virus (NPV) progresses up to $5^{\text {th }}$ day of $5^{\text {th }}$ instar for silkworm B. mori to carbohydrates utilization as a source of energy required for biosynthesis of viral constituents. Mallikarjuna et al., (2002) mentioned that, the total content of carbohydrates were decreased as a developed disease and reasonable to mentioned that, carbohydrates used as a source of energy required for fungus development and growth. The haemolymph of insect has a large pool of sugars and it is reasonable to assume that the depletion of glycogen in the 
tissues target may be result of utilization as an energy source required for metabolism increased in host ceased by infection Kobayashi and Kawase, 1981.

3- Effect of fungi on haemolymphlipids content.

Data given in Table (3) indicated that the changes in the total content of lipids in larvae of S. Littoralis treated with the tested four entomopathogenic fungi at the $1^{\text {st }}, 2^{\text {nd }}$, $3^{\text {rd }}$ and $4^{\text {th }}$ days.

The results showed that a significant change in the total content of lipids in the larvae treated with the entomopathogenic fungi tested as compared with untreated the larvae (control). P. lilacinus $(5.14 \mathrm{mg} / \mathrm{ml})$ and $L$. antillanum $(4.5 \mathrm{mg} / \mathrm{ml})$ were recorded the highest increase in lipid content, while the lowest value was recorded with B. bassiana $(2.7 \mathrm{mg} / \mathrm{ml})$ compared to control $(2.5 \mathrm{mg} / \mathrm{ml})$ in $1^{\text {st }}$ day larvae of $S$. littoralis. All tested fungi increase in lipid content at $2^{\text {nd }}$ day and the highest increasing values were achieved by B. bassiana $(5.12 \mathrm{mg} / \mathrm{ml})$, L. antillanum $(4.08 \mathrm{mg} / \mathrm{ml})$ compare with control $(2.48 \mathrm{mg} / \mathrm{ml})$. Also, there was significant increasing in lipid content of larvae of
S. littoralis at $3^{\text {rd }}$ day treated with $B$. bassiana $(4.84$ $\mathrm{mg} / \mathrm{ml})$, L. antillanum $(4.82 \mathrm{mg} / \mathrm{ml})$ and $P$. lilacinus $(4.76$ $\mathrm{mg} / \mathrm{ml})$ compared to control $(3.32 \mathrm{mg} / \mathrm{ml})$. On the other hand, there was reduction in lipids content with $M$. anisopliae $(2.40 \mathrm{mg} / \mathrm{ml})$. The four tested fungi showed increasing in lipid content of the treated larvae at $4^{\text {th }}$ day and the significant increasing recorded with $B$. bassiana $(7.62 \mathrm{mg} / \mathrm{ml})$ followed by L. antillanum $(5.30 \mathrm{mg} / \mathrm{ml})$ compared to control $(3.40 \mathrm{mg} / \mathrm{ml})$

Lipid content level was increased when larvae of $S$. Littoralis treated with the tested fungi and ranged from

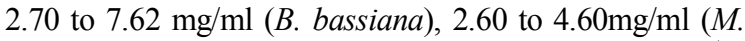
anisopliae), 4.50 to $5.30 \mathrm{mg} / \mathrm{ml}$ (L. antillanum) from $1^{\text {st }}$ to $4^{\text {th }}$ day. While, $P$. lilacinus caused decreasing in lipid content level from 5.14 to $3.88 \mathrm{mg} / \mathrm{ml}$ at the same time. On the other hand, lipids content of control approximately not changed (Table 3). Therefore treatment of larvae of $S$. littoralis with the tested fungi tend increase of lipid content level with time increasing.

Table 3. Effect of five fungal pathogens on lipids contents $(\mathrm{mg} / \mathrm{ml})$ in haemolymph of $5^{\text {th }}$ instar larvae of Spodopteralittoralis

\begin{tabular}{|c|c|c|c|c|}
\hline \multirow{3}{*}{ Treatments } & \multicolumn{4}{|c|}{ Protein Mean \pm S.D $(\mathrm{mg} / \mathrm{ml})$} \\
\hline & \multicolumn{4}{|c|}{$\begin{array}{l}\text { Time (days) } \\
\end{array}$} \\
\hline & $1 \mathrm{st}$ & 2nd & 3rd & 4th \\
\hline Control & $2.50 \pm 0.40 \mathrm{e}$ & $2.48 \pm 0.22 f$ & $3.32 \pm 0.11 \mathrm{c}$ & $3.40 \pm 0.33 \mathrm{f}$ \\
\hline M. anisopliae & $2.60 \pm 0.06 \mathrm{de}$ & $2.70 \pm 0.17 \mathrm{e}$ & $2.40 \pm 0.15 \mathrm{~d}$ & $4.06 \pm 0.06 \mathrm{~d}$ \\
\hline P. lilacinus & $5.14 \pm 0.20 \mathrm{a}$ & $3.56 \pm 0.09 \mathrm{c}$ & $4.76 \pm 0.40 \mathrm{a}$ & $3.88 \pm 0.04 \mathrm{e}$ \\
\hline L. antillanum & $4.50 \pm 0.32 b$ & $4.08 \pm 0.04 b$ & $4.82 \pm 0.10 \mathrm{a}$ & $5.30 \pm 0.29 b$ \\
\hline B. bassiana & $2.70 \pm 0.08 \mathrm{~d}$ & $5.12 \pm 0.02 \mathrm{a}$ & $4.84 \pm 0.25 \mathrm{a}$ & $7.62 \pm 0.17 \mathrm{a}$ \\
\hline F value & $446.95 * * *$ & $1665.49 * * *$ & $1713.56 * * *$ & $2049.52 * * *$ \\
\hline LSD0.05 & 0.163 & 0.074 & 0.074 & 0.104 \\
\hline
\end{tabular}

Our results are agreement with Nirupama, (2015) found that, lipid concentration level in the haemolymph of silkworm, B. mori ( $5^{\text {th }}$ instar) was high at the initial three days and simultaneously decreased their level at the end of $5^{\text {th }}$ day in inoculated batches, while, but, the control gradually increased. The results of Gabarty, (2011) showed a significant increase in the total content of lipids in the greasy cut-worm Agrotis ipsilon (Huf.) larvae treated with the two pathogenic fungi, B. bassiana and M. anisopliaeas compared with control. In contrast to the present study, the obtained data of Nada, (2015) showed that total lipids decreased significantly when adults of $N$. virdula treated with $M$. anisopliae and their no significant differences during 24, 48, 72 hours.

Lipids are important source of energy reserves compared to carbohydrates. Lipids can supply as much as eight time more energy per unit weight (Beenakkers et al., 1985 and Ali, 2011). The important components of cuticle are Lipids, which help in acylation of glucose-6-phosphate during chitin synthesis (Wyatt, 1967). Lipids are fundamental for structural components of cells and serve as a source of metabolic energy. The lipid can be mobilized rapidly during starvation, embryogenesis, oogenesis and moulting in the fat body so considered as an energy reserve and is used to sustain continuous muscular activity (Gilbert and Chino, 1974).

The biochemical parameters such as, proteins, carbohydrates, lipids, nucleic acids etc., vary significantly during the life cycle of all living organisms. Metabolic changes play an important role in understanding the interaction between the host and pathogen as a part of a survival strategy. Several biochemical and physiological alterations caused in insect tissues owing to pathogenic infections (Martignoni, 1964; Shigematsu and Noguchi, 1969). The infection progress by a pathogen in the host tissue can be monitored by studying the degree of variation in metabolic constituents (Rajitha and Savithri 2014).

Generally, in the present study, biochemical changes occurred in the total protein, carbohydrate and lipid contents in the haemolymph during the course of fungi infection. The present findings support that infection with entomopathogenic fungi had different effects on the $5^{\text {th }}$ instar of $S$. littoralis, particularly as they changed haemolymph nutrients contents (e.g. Carbohydrates, lipids and proteins).The increase and decrease in the proteins, carbohydrates and lipids contents of heamolymph from the $1^{\text {st }}$ day up to $4^{\text {th }}$ day after inoculated due to infection by pathogen of fungi have important role in S. littoralis growth and development. Infection of $S$. littoralis with fungi tend to its stimulated their protein, carbohydrate and lipid utilization in order to meet requirements of toxic stress. Under fungi infection there are correlation between the changes in the concentration of these bio-molecules and the degree of their absorption, interconversion and utilization and the high toxicity of the $S$. littoralis larvae.

The biochemical results showed these major changes in protein, carbohydrate and lipid content level in infected causes for high toxicity of the $S$. littoralis larvae 
showing significant variation in their contents. The results indicated fungi infection caused physiological and biochemical changes in the cotton leaf worm. Metabolic changes play an important role in understanding the interaction between the host and pathogen as a part of a survival strategy. Metabolite depletion by the entomopathogenic fungi could cause physiological imbalances in the host that lead to changes in enzyme activates and a reduction in haemolymph protein, carbohydrates and lipid contents.

\section{CONCLUSION}

In conclusion, the results of this study clearly indicated that, fungi caused a sharp disturbance in the protein, carbohydrate and lipids contents under highly toxic effect by fungus which produced a toxins impact on the leaf-worm $S$. littoralis, consequently these biocontrol agents can used as a promising environmentally friendly alternatives of the synthetic chemical insecticides against this destructive pest $S$. littoralis. However, more research is needed to investigate the in vivo and in vitro determination of virulence factors of entomopathogenic fungi.

\section{REFERENCES}

Abou El-Ghar, G. E. S.; Khalil, M. E. and Eid, T.M., (1996). Some biochemical effects of plant extracts in the black cutworm, Agrotis ipsilon (Hufn.) (Lep.,Noctuidae). J. Appl. Ent., 120: 477-482.

Ali, Rehab M. S. (2011). Combined effect of gamma radiation and entomopathogenic nematoda on some store product pests. Ph. D., Thesis, Fac. of Agric., Ain Shams Univ.

Beckage N.E., (2008).Insect Immunology. Academic press /Elsevier, San Diego, p348.

Beenakkers, A. m. Th., Van Der Horst, D.J. and Van Marrewijk, W. J.A. (1985). Biochemical processes directed to flight muscle metabolism. In : G. A. Kerkut and L. I. Gilbert (eds.), Comparative Biochemistry and Physiology, 10:451-486.

Bradford, M. M. 1976. A rapid and sensitive method for the quantitation of microgram quantities of proteins utilizing the principle of protein-dye binding. Anal. Biochem., 72:248-254.

Dubois, M.; K. Gilles; J. Hamilton; P. Rebers and F. Smith 1956. Colorimetric method for determination of sugars and related substances. Analytical Chemistry, 28(3):350-356.

Gabarty Ahlam Abd EL- Wahed 2011 Combined effect of gamma radiation and some fungal control agents on the greasy cutworm Agrotis ipsilon (Huf.) Ph.D. Thesis, Faculty of Science for Girls Al- Azhar University Cairo- Egypt.

Gabarty, A.; El-Sonbaty; S. M. and Ibrahim, A. A. (2013).Synergistic effect of gamma radiation and entomopathogenic fungi Beauveria bassiana and Metarhizium anisopliae on the humoral immune enzyme response in cotton leaf worm Spodoptera littolaris (Boisd). Egypt. Acad. J. Biolog. Sci., 6 (3): $1-10$.
Gilbert, L. I. and chino, P. 1974. Transport of lipids in insects. J. Lipid Res., 15: 439-456.

Horie, Y., Watanabe, K. \& Sakamoto, E. 1982. Evidence of stepwise digestion of protein in the digestive system of the silkworm, Bombyx mori. App. Ent. Zool., 17: 358-363.

Knight JA, Anderson S, and Rawle JM (1972). Chemical basis of the sulfo phosphovanillinreaction for estimating total serum lipids. Clin. Chem.18 (3): 199-202

Kobayashi M. and S. Kawase. (1981) Pattern of nucleicacid synthesis in isolated pupal abdomens of the silkworm, Bombyx mori (Lepidoptera: Bombycidae), infected with nuclear polyhedrosis virus. Applied Entomology and Zoology. 16(4): p. 501-502.

Lee KP, Behmer ST, Simpson SJ, Raubenheimer D (2002). A geometric analysis of nutrient regulation in the generalist caterpillar Spodoptera littoralis (Boisduval). J. Insect. Physiol. 48: 655-665.

Mallikarjuna, M. M. Balavenkatasubbaiah, B. Nataraju and V. Thiagrajan (2002) Effect of systematic fungicide on total haemocyte count and haemolymph biochemical changes in silkworm Bombyx mori L. infected with Beauveria bassiana. Int $\mathrm{J}$ Indust Entomol 5: 189-194.

Mallikarjuna, N.; Kranthi, K. R.; Jadhav, D. R.; Kranthi, S. and Chandra, S. (2004). Influence of foliar chemical compounds on the development of Spodoptera litura (Fab.) in inter-specific derivatives of groundnut. J. App. Entom., 128:321-328.

Martignoni ME.1964.Mass production of insect pathogens. In:De Bach P Ed. Biological control of insect pest and weeds.Reinhold,New York.;579-609.

Martignoni, E. 1964. Pathophysilogy in the insect. Ann. Rev. Entomol., Pp. 179-206.

Meshrif W. S. , Rohlfs M. , Hegazi M. A. M., Shehata M.G., Barakat E. M. S. and Seif A. I. (2010).Humoral response and plasma changes of Spodoptera littoralis (Lepidoptera: Noctuidae) following injection with the entomopathogenic fungi: Beauveria bassiana and Nomuraea rileyi Proc. 6th Int. Con. Biol. Sci. (Zool.), 6:96 - 102.

Nada Maha S. 2015 Response of green stinkbug nezara viridula (linnaeus), to the activity of entomopathogenic fungi Beauveria bassiana and Metarhizium anisopliae J. Plant Prot. and Path., Mansoura Univ., Vol.6 (12): 1633-1644,

Nation JL. 2008 Insect physiology and biochemistry. $2^{\text {nd }}$ edition.CRC press. New York. 544 pp.

Nirupama R. 2015 Biochemical studies on total protein, carbohydrate and lipids content level during the infection by fungi white muscardine disease of silkworm, Bombyx mori L.Mun.Ent. Zool. Vol. 10, No. 2.

Padma SreeVidya Devi P and Ramani Bai M 2015 Biochemical activity in the haemolymph of silkworm, Bombyx moriL. during the infection of fungal pathogen, Beauveria bassiana(Bals) Vuill International Journal of Multidisciplinary Research and Development Volume: 2, Issue: 5, 320-322. 
Pawar VM and Ramakrishnan N 1977. Biochemical changes in larval haemolymph of Spodoptera litura (Fabricius) due to nuclear polyhedrosis virus infection. Indian Journal of Experimental Biology; 15: 755-758.

Rajitha K and Savithri G.2014. Amino acid profiles in the haemolymph of silkworm, Bombyx mori L. infected with fungal pathogen, Beauveria bassiana (Bals) vuill. International Journal of Applied Biology and Pharmaceutical Technology, 5(1): 163-166.

Sarma, B.J. M.V. Samson, V. Siva Prasad, M. B. Venkatasubbaiah and R.K. Datta, (1994) Biochemical changes in the haemolymph of the silkworm Bombyx mori L during the progressive infection of nuclear polyhedrosis virus (BmNPV). Sericologia; 34: 539-541.

Shigematsu, H. and Noguhi, A. 1969. Biochemical studies on the multiplication of a nuclear polyhedrosis virus in the silkworm, Bombyx mori. II. Protein synthesis in the larval tissue after infection. J. Invertebr. Pathol., 14: 301-307.
Vidhya, D., P. Rajiv and Nalini Padmanabhan 2016 Impact of entamopathogenic fungal infection on the detoxifying enzyme in cotton leaf worm, Spodoptera litura (fabricius) int $\mathrm{j}$ pharm bio scioct ; 7(4): (b) $943-948$

Vincent C, Goettel MS, Lazarovits G. (2007). Biological control, a global perspective. CABI publishing. Oxfordshire, United Kingdom, Pages 300-311.

Wyatt, G. R. 1967. The biochemistry of sugar and polysaccharides in insects. Adv. Insect Physiol., 4: 287-360.

\section{تأثير العدوى الفطرية الممرضة للحشرات على بعض المحتويات البيوكيميائية في هيموليمف حشرة دودة ورق القطن

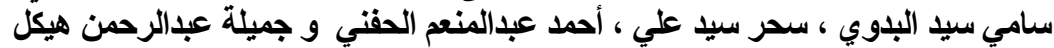

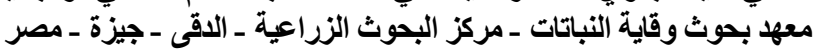

من خلال الدراسة تم تقييم وتقدير محتويات الكربو هيدرات والدهون والبروتينات الكلية في هيموليمف يرقات العمر الخامس لدودة ورق القطن التي

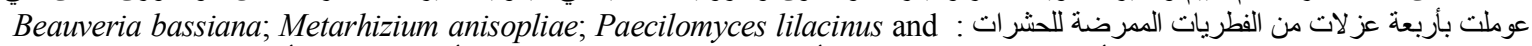

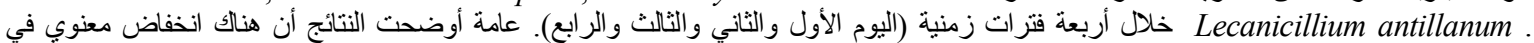

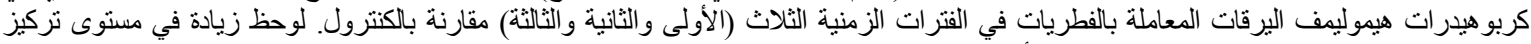

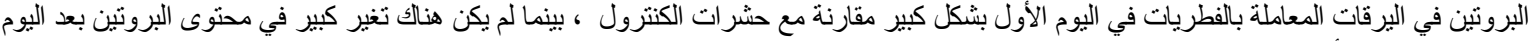

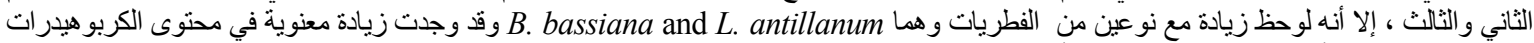

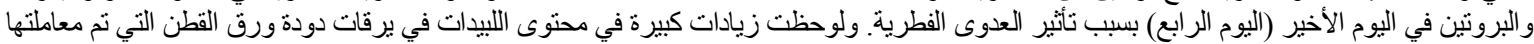



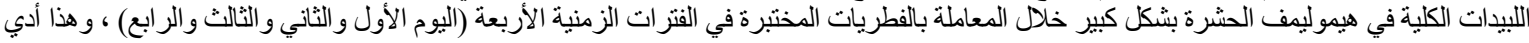

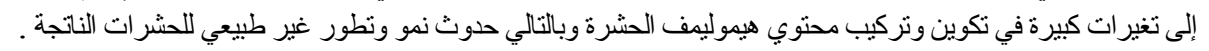

